\title{
Global Citizen Preparation: Enhancing Early Childhood Education through Indonesian Local Wisdom
}

\author{
Obby Taufik Hidayat ${ }^{1, *}$, Ahmad Muhibbin ${ }^{1}$, Wibowo Heru Prasetiyo ${ }^{1}$, Yulianto Bambang Setyadi ${ }^{1}$, \\ Hermi Yanzi ${ }^{2}$, Rizky Drupadi², Jack McGregor Johnstone ${ }^{3}$, Jagad Aditya Dewantara ${ }^{4}$ \\ ${ }^{1}$ Department of Civic Education, Universitas Muhammadiyah Surakarta, Indonesia \\ ${ }^{2}$ Department of Civic Education, Universitas Lampung, Indonesia \\ ${ }^{3}$ Interpreting and Translation Studies, Monash University, Australia \\ ${ }^{4}$ Department of Civic Education, Universitas Tanjungpura, Indonesia
}

Received June 16, 2020; Revised August 10, 2020; Accepted August 25, 2020

\section{Cite This Paper in the following Citation Styles}

(a): [1] Obby Taufik Hidayat, Ahmad Muhibbin, Wibowo Heru Prasetiyo, Yulianto Bambang Setyadi, Hermi Yanzi, Rizky Drupadi, Jack McGregor Johnstone, Jagad Aditya Dewantara, "Global Citizen Preparation: Enhancing Early Childhood Education through Indonesian Local Wisdom," Universal Journal of Educational Research, Vol. 8, No. 10, pp. 4545-4554, 2020. DOI: 10.13189/ujer.2020.081023.

(b): Obby Taufik Hidayat, Ahmad Muhibbin, Wibowo Heru Prasetiyo, Yulianto Bambang Setyadi, Hermi Yanzi, Rizky Drupadi, Jack McGregor Johnstone, Jagad Aditya Dewantara (2020). Global Citizen Preparation: Enhancing Early Childhood Education through Indonesian Local Wisdom. Universal Journal of Educational Research, 8(10), 4545-4554. DOI: 10.13189/ujer.2020.081023.

Copyright $\bigcirc 2020$ by authors, all rights reserved. Authors agree that this article remains permanently open access under the terms of the Creative Commons Attribution License 4.0 International License

\begin{abstract}
In a globalized world, young people are expected to have critical thinking and communication abilities, such as collaboration and technological skills. Both skills are imperative to equip them to participate in an international environment. However, due to a lack of early childhood education, youths in Indonesia also have less innovativeness and competency. This study aims to discover an ethical culture that enhances early childhood education by using the concept of local wisdom. This research was conducted in one of the Indigenous communities in Indonesia which were the Sundanese Community in Cireundeu, West Java. The qualitative approach used the descriptive method and revealed the consciousness of the Indigenous people in Cireundeu to engage in traditional Sundanese cultural practices by preparing their children to become ethical human beings, as well as being productive and informed global citizens. The results show that the community has implemented decent early childhood education, which is designed to prepare youths who actively engage as global citizens. The implementation of this study can be applied not only to children in Cireundeu but also to children all over the world.
\end{abstract}

Keywords Early Childhood Education, Global
Citizens, Indonesian Local Wisdom, Globalization

\section{Introduction}

As a developing country, Indonesia has not adequately prepared its youth to respond to the challenges of globalization effectively. Based on The World Economic Forum data from the Global Competitiveness Report, 2011 to 2012, Indonesia is ranked 46th in terms of its education quality[1]. The fact indicates that Indonesia has a lack of good human resources, which causes a lack of optimized education, especially in early education as the fundamental element needed [2].On the other hand, the dynamics of globalization in the era of the ever-accelerating fourth industrial revolution make it a necessity for all people around the world to respond to its development with their capacities and characters [3-5]. Accordingly, the quality of education affects the preparedness of global citizens and the development of education related to moral \& character, cosmopolitan transformation, liberal learning, and metacognitive capacities [4]

Indonesia is expected to have a modality to increase 
economic growth as it has such benefits of a demographic dividend, which means that there will be a large number of productive-aged citizens [6]. Therefore, Indonesia should respond to the challenge by preparing citizens who are knowledgeable and global-minded to increase global competitiveness $[4,5,7]$. Globalization has a significant influence on various aspects of changes in life [8]. Besides, most countries are directly or indirectly involved in the dynamics of the rapid globalization process. In this context, globalization allows each individual to develop themselves, live together comfortably, and promote tolerance towards world diversity. All of these are called cosmopolitan conditions[9]. Nevertheless, some countries accept all the benefits of globalization without keeping the national or local culture from being degraded.

Recently, Indonesia has attempted to create competitive global citizens by transforming the national education system, such as amending the national education curriculum [10]. These changes include the implementation of character education as an effort to motivate children to develop skills and attitudes. To create a generation of good global citizens, the government needs to prioritize embedded values and characters in the curriculum, such as peace, empathy, tolerance, and respect for those who come from different cultures [11]. Unfortunately, character education at elementary and secondary schools in Indonesia has not been strongly implemented with academic education, which results in students not being ready to become global-educated citizens[12]. In general, the concept of teaching and learning is heavily dependent on conventional learning methods (teacher-centered), which are not optimal in preparing students to become global citizens. Therefore, active participation is needed to empower individuals themselves. It means that individuals have the ability to create social, political, economic, or other change. Furthermore, they optimize to manage or influence and engage in actions that affect others [13]. In the future, these individuals will become responsible leaders in their roles as global citizens.

Meanwhile, educating students to become global citizens is an ambitious goal within the fourth industrial revolution. It could be related to the further ambition that students will understand and reconcile a set of complex values and goals in order to compete globally [14]. Discussing the concept of global citizens is often associated with an ideal cosmopolitan concept, as it is assumed that the need for this concept stems from an increasing level of global connectivity. It also involves the exchange and integration of various beliefs, values, and materials that lead to the development of all citizens on a global scale [15]. Therefore, it is necessary to shape a globally recognized identity adequately. Global citizens are identified as individuals who have intellectual development in their lives, together with an attitude of openness, tolerance, respect, and responsibility towards themselves, others, and the planet [16]. It means that individuals can understand their positions not only as citizens of a nation but also as global citizens in a multicultural world. Hence, one of the essential components of being a good global citizen is a willingness to appreciate and respect others. They might understand others across national borders and cultural differences, despite it being difficult for people to show empathy for others [17].

In Indonesia, preparing global citizens is close to the aims of education as it could be assumed that Indonesia has characteristics derived from the diversity of ethnicities, cultures, and languages, namely local wisdom [18]. There is a difference between local and global. For instance, wisdom is a general term that reflects the conduct and compassion. However, it is essential to note that not all of the connotations are sectarian. Thus, it does not mean that the practice of traditional activities, which contain local wisdom cannot be global as it must be understood that local wisdom has a broad meaning, which is not limited by space and time[3]. The meaning of local wisdom does not have to be a legacy from one generation to another as it might be formed as something that has emerged from daily activities. Local wisdom places more emphasis on the aspects of locality and places that have thoughtful ideas and mindsets [19]. Therefore, the values of local wisdom may represent some characteristics of good global citizens and personal qualities that are expected and accepted by the global community.

Attention to Character Education is an important implication in early childhood to make adults become good and smart citizens in the future because in essence good character is needed to lead ethical, productive, and fulfilling lives [20]. Character education covers several aspects, including social \& emotional learning, moral education, life skill training, community service, health education, health prevention, violence prevention, integrity instillation, rationality, and ethics development $[21,22]$. The purpose of character education is to develop children as people who are insightful, caring individuals who prioritize justice, critical and intellectual thinking and individuals who use their best capacity to do their best and understand the purpose of life $[23,24]$. According to Bates Character education, it contributes to each individual in the "three Rs" of education - resilience, respect, and responsibility [25].

Character education develops continuously in accordance with the development of time periods, thoughts and ideas. The concept raised by Cunningham states that character is a lesson that must be taught at a formal and non-formal level [26]. This includes character, moral or behavioral values that are enforced in social life, this is better known as social normative characters[27]. Normative characters include several aspects of personality, such as optimistic attitude, honesty, simplicity, fairness, and being able to manage emotions. Whereas the concept that was theorized by Thomas Lickona(2005), that character is a good behavior that is inherent in a person's personality includes knowledge, social care, and behavior 
based on values and norms in the community[20,25,28]. Specifically on the concept of Character Education for Early Childhood, moral development in children is in accordance to their age level. Piaget revealed that moral development in humans includes three processes, namely (1) premoral, (2) moral realism, and (3) moral relativism [29]. From this theory, it explains about early childhood development, children are not yet familiar with the rules, social morals, ethics, and decency[24,30]. Then in the next stage, developing children to enter the level of adolescents and adults who are more likely to know the rules, morals, ethics, and immorality and can act according to rules in society[26,31].

Several studies on local wisdom as the basis of character education in the globalization era have been conducted [32]. Report that participation and support in Indigenous communities could consistently be applied to build the civic culture of a society. A study in Kasepuhan Ciptagelar describes local wisdom as social solidarity, environmental awareness, democracy, honesty, responsibility, and creativity. Local wisdom is considered as a guide to maintaining their survival in the globalized era [33]. A study in Kalibiru, Lopati Yogyakarta, shows that local wisdom prioritizes mutual cooperation among their communities, combined with innovation and motivation to develop a tourism village. As a result, these efforts have an impact on the local economy [34]. The concept of local wisdom in Indonesia means the diversity that exists in society. It suggests that the values of local cultures need to be maintained together with national and global cultures. This maintenance is intended to encourage people to adopt a global perspective without ignoring their ethnicity and national identities $[7,35]$. However, there is a lack of research that investigates the effect of local wisdom as a character education pillar in a pedagogical context. Accordingly, this study aims to investigate character education by implementing local wisdom since early childhood as cultivating character at an early age. It is imperative because childhood is the right development stage to experience maturation and interactive processes. Scholars argue that childhood education would involve development in the regularity of perception, motor, cognitive, language, social, emotional, and self-control skills [36]. So, how do young children in the Cireundeu Indigenous community grow up to become smart, healthy and productive global citizens?

Therefore, this study seeks to answer three questions:

1. How does the Sundanese local wisdom in Indonesia build harmony with globalization?

2. How to implement character education in Indonesia based on local wisdom in the globalized era?

3. Based on the Sundanese local wisdom, how does the implementation of education at an early age prepare young children to be global citizens?

\section{Research Method}

In this study, the qualitative approach and ethnographic method were employed to investigate and understand the practices of the Cireundeu Indigenous community in implementing character education at an early age based on Sundanese local wisdom for the preparedness of global citizens. The rationale stance to use an ethnographic method has several advantages. For instance, it provides a space for research on people, society, and culture, not only documents and literature. It emphasizes how to obtain empirical data based on the community's experience. Also, it focuses on observation as a participant [37]. The researchers not only observed and conducted interviews but also participated directly in the daily lives of the Cireundeu community. By entering into their community, the researchers can uncover and study their lifestyle, logic rhythm, and socio-cultural contradiction.

The study was conducted in the Cireundeu village, particularly in the Indigenous community in the Cireundeu village. Geographically, this area is located in the Leuwigajah village, in the south of Cimahi City, West Java. The Leuwigajah village has regional boundaries, including an altitude of 700 meters above sea level with a temperature of around 21 degrees Celsius up to 29 degrees Celsius. The Leuwigajah Urban Area itself has a large area of around $393,473 \mathrm{~km}^{2}[38]$.

This study used purposive sampling, which is effective in obtaining information from an expert who understands a particular case [39]. Accordingly, the process in selecting informants was based on several reasons, including; (1) willingness to be informant; (2) a member of the Indigenous people of Cireundeu; (3) stakeholders who had lived in the Cireundeu village for more than ten years. As a result, the number of informants was 18 informants $(8$ males and ten females), two heads of the kampong (local village), ten residents, and six cultural stakeholders in Cireundeu.

The collecting data technique was divided into three phases, including observations, personal interviews, and documents [40]. In the first phase, researchers came to the Cireundeu village to directly observe and assess the characteristics of the Indigenous people and the conditions of the village. Researchers resided at an Indigenous home to get a depth observation. In the second phase, researchers conducted personal-directed interviews with informants consisting of customary leaders, stakeholders, and several Cireundeu Indigenous residents. The second phase aims to gather information about early childhood education based on Sundanese local wisdom. Researchers asked for permission from each informant to be interviewed and guaranteed that the informant's identity will be confidential. The informants answer all questions following the questionnaire protocol. The last phase was literature studies, including photos, certificates, and the preliminary 
treatise. In this phase, researchers collected some photos from the Cireundeu Indigenous community. They received certificates of appreciation from the Indonesian government, non-governmental organizations, and foreign parties. The preliminary treatise on the formation of Cireundeu's local wisdom was obtained because they succeeded in educating people from an early age in preserving local wisdom.

All data were analyzed using data coding methods [41]. The data analysis included creating content analysis tables, identifying which code will be used, and re-arranging the findings so that the data groups are following the categories obtained. A referential qualitative researcher is trying to understand what the data means from the beginning of the research period. The data is being collected at each stage of the process [42].

\section{Results and Discussion}

\section{Description of Sundanese Local Wisdom that Can Harmonize with Globalization}

The effects of globalization need a wise response. For example, Indonesia, which has a variety of cultures and local customs, should retain its identity regardless of the accelerating globalization.In order to do the responsibility, people should be harmony between local and global wisdom, which can be seen in the response from the Sundanese ethnic group represented by the Indigenous people of Cireundeu in dealing with globalization. They are trying to preserve their local wisdom and, at the same time, trying not to be isolated from globalization. Therefore, most of the Indigenous people there respond to the development of globalization openly and accept foreign influences that can help them further develop. However, there is a small portion of them that are still untouched by modern life. Lastly, some of them give mediocre responses to globalization. The data is presented in Table 1 below.

Table 1. Perception of the Indigenous People Responding to Globalization

\begin{tabular}{|c|c|c|}
\hline No. & Attitude & $\begin{array}{c}\text { Number of } \\
\text { Respondents }\end{array}$ \\
\hline 1 & Positive & 36 \\
\hline 2 & Negative & 5 \\
\hline 3 & Neutral/Balanced & 9 \\
\hline Total & & 50 \\
\hline
\end{tabular}

The Indigenous people in Cireundeu share the same characteristics as other Indigenous people in Indonesia who uphold the practices of traditional activities that are distinctive and passed on from one generation to another. The uniqueness seen from the Indigenous people there includes an independent food fulfillment system (their staple food differs from Indonesian society in general), a local belief system (SundaWiwitan), and an open mindset of the Indigenous people. Whereas "MibapaKaZaman" means Indigenous people can still accept the positive effects of globalization to continue to develop themselves. This principle illustrates that Sundanese local wisdom there is not isolated by globalization as they think accepting globalization will advance their lives. In line with Potrafkethat globalization has a beneficial effect; evidence empirically shows that social globalization also promotes human development, gender equality, and tolerance of different human lifestyles [43]. One respondent showed a positive attitude by looking at the impact of globalization. He said,

"We, as Indigenous people, are still preserving customs, local culture, and beliefs that are loaded with local wisdom. They are forms of local wisdom that our ancestors championed in defending our group from all the challenges of life going forward. As our staple food is cassava, which is different from rice, the staple food of Indonesia in general. It is a history of past struggle in anticipating food limitations and fostering independence. However, besides the typical and strong form of local wisdom of the Indigenous people there, we also do not disregard foreign influences that improve the quality of our lives. It is different from other Indigenous people, who do not want to be touched by modern life."

Other respondents who showed a positive attitude that local wisdom could integrate harmony with globalization. He said,

"The Cireundeu community is open to foreign influences and globalization, such as using internet communication tools, using modern vehicles, and wearing clothes. Following the development of education and there are even members of the Cireundeu community who have taken tertiary education and other means of education. I consider the values of local wisdom in Cireundeu to compensate for the technological progress or influence of globalization, with some attitudes such as holding the value of honesty consistently in acting in the global era and giving freedom to every Cireundeu Indigenous community to accept and use foreign influences responsibly. The response of the Cireundeu community is based on the mandate of the Cireundeu Indigenous people's ancestors who must continue to develop themselves for prosperity while maintaining a sustainable local culture".

Conversely, some respondents have a negative view of globalization, which is shown by the negative impact of globalization on the existence of local wisdom, including the emergence of Western lifestyle behavior, loss of identity, rejection of the culture itself, moral degradation, and diminished sense of nationalism. It is a challenge for the Indigenous people of Cireundeu not to accept 
globalization to preserve their local wisdom and protect the next generation. In contrast to [44], where the relationship between globalization and localization in education is dynamic and interactive, globalization that is localized by values in education can create more value; local development can be induced in the processof cultural and operational change. The following shows the Indigenous Cireundeu people's negative view of globalization. One informant said:

"The Indonesian people currently lack a strong national identity as most of us prioritize personal interests for profit, and high primordialism, we only care about ourselves and are easily influenced by foreign cultures that enter our country. These negative things can lead to the degradation of Indigenous culture and local wisdom in Indonesia due to the impact of globalization, which makes them love foreign cultures, such as Korean, Japanese and Western cultures more than their own."

Not all Indigenous Cireundeu communities can accept globalization as a small number of them consider globalization as a threat to the unity of community groups and the preservation of Sundanese local wisdom. Some respondents do not respond positively or negatively, so they tend to have a neutral attitude. The following is an illustration of a neutral response to globalization from the Indigenous Sundanese people in Indonesia. One of them said:

"Nowadays, globalization has entered into all forms of public life throughout the world. Indonesian society is no exception as change continues to occur in all aspects of people's lives, such as in information technology (IT), economic affairs, social programs, etc. This change is natural, and people all over the world are inevitably affected by it. The impact of globalization is not only harmful, but it can also have a positive impact on people's lives if responded to wisely".

Based on the description above about the description of the Indonesian people's response who still uphold local wisdom, we calcify the character of the Cireundeu Indigenous people into several traits such as a) having a democratic spirit; b) having a spirit of independence' c) having a high level of solidarity (Collectiveness); d) upholding honesty values (Integrity); e) having self-appreciation; f) acting responsibly, and; g) being Consistent and Creative.

According to the description above, about Sundanese local wisdom, harmony can develop with globalization. This study classifies the Sundanese Indigenous people concerning some characteristics of local wisdom: Upholding respect (respecting one another, not only for Indigenous people), showing independence (not too dependent on others), showing high solidarity ( having a strong sense of kinship), standing strong (having strong principles), being open (accepting new things positively), having integrity (maintaining consistency between words and deeds) and encouraging participation (providing mutual cooperation in all development). The description of the people's characteristics still upholds local wisdom in responding to globalization, namely social solidarity, environmental awareness, honesty, democracy, creativity, and responsibility [33]. Meanwhile, it seems that the positive attitude of accepting globalization that integrates harmony with Sundanese local wisdom was discovered. Indigenous people in Cireundeu would continue to preserve local wisdom, such as upholding the basic principles of food security in consuming cassava staples (constellations), adhering to the SundaWiwitan beliefs, and enforcing Sundanese customs, but it does not reject the progress of globalization [45].

Sundanese local wisdom for the Cireundeu Indigenous people runs in harmony with global wisdom in a sustainable manner[32] as they do not have problems with globalization or modern life. This is different from other traditional communities or villages that are still isolated from modern life. It should be noted that globalization provides many benefits in life today, especially responding to the fourth industrial revolution. There are some positive effects of globalization, which are reducing unemployment and having positive economic growth because globalization provides a road map for trade between countries [46]. Likewise, accepting globalization has a positive impact on the quality of better education by sharing knowledge between countries, especially in the field of Information and Communication Technology (ICT), because the progress of ICT enables the learning process to be more effective and efficient in producing advancing education outcomes to national development[47].

\section{Description of Character Education in Indonesia Based on Sundanese Local Wisdom}

This research shows that Indigenous Cireundeu people who uphold the values of local wisdom can shape their character as citizens. Table 2 indicates that almost $100 \%$ of respondents have good character, although around $4 \%$ of respondents still do not have the desired character. Furthermore, the Indigenous people there always behave well and morally because they are fearful whenever they make mistakes or sins. These Cireundeu ancestral traditions manage to instill a mindset in the community sustainably, with full awareness and without coercion.

Table 2. The Implementation of Character Education Based on Local Wisdom

\begin{tabular}{|c|c|c|c|}
\hline No. & Description & Total & 'Percentage \\
\hline 1 & Good & 48 & $96 \%$ \\
\hline 2 & Bad & 2 & $4 \%$ \\
\hline & Total & 50 & $100 \%$ \\
\hline
\end{tabular}


The following is a note about the character education of the Indigenous people in Cireundeu, based on the values of their local wisdom. One informant said:

"The life practices of the Cireundeu Indigenous people have a view on the wise concepts or ideas created by traditional Cireundeu ancestors. They educate the next generation by instilling godly values, being kind, respecting each other, actively contributing to the common interest, caring for the natural environment, which must be safeguarded, being independent, and being responsible for all decisions and actions are taken. As for their method of educating the next generation, the character of children in a way to tell the history of ancestors sustainably about the struggle of ancestors in the Cireundeu Indigenous community to live independently and prosperously. They also educate children not only with words but by showing examples of good behavior to children as a role model. With this method, it is successful in forming the character of children without coercion or pressure, but the awareness of the children themselves because of shame if the parents show good character while the child is not like the character of his/her parents".

On the other hand, there are a few Indigenous Cireundeu people who lack good character, according to values. One informant said:

"Cireundeu is inhabited by Indigenous and non-Indigenous communities. This condition allows some members of the community to show weakness in self-control because of the negative influence of a culture that does not hold Cireundeu's local wisdom. For example, the appearance of individualistic traits, lack of mutual respect, weak morals, and weakened confidence in their beliefs. This is because one of the principles of the Cireundeu Indigenous people is that it allows marriage to individuals who are not Indigenous. In addition, Indigenous people can live together in a complex with communities that are not Indigenous to Cireundeu, so at least influences from outside of Cireundeu can form characters that are incompatible with the Pancasila (the five principles)".

This study identifies that character education has been successfully implemented through Cireundeu's local wisdom values, with only a small amount of shortcomings in character education due to adverse external influences. In essence, local wisdom makes sense and is wise. In Indonesia, it appears that local wisdom has a positive meaning and is manifested as a strategy, mindset, or series of abstract and concrete ideas to build a better image of local knowledge that is not always interpreted positively [19]. Likewise, in the Cireundeu community, many have positive values from their local wisdom that can be interpreted as character education. AsMurray said, someone who has a character is someone who has specific and unique traits, but that character can be good, bad, or neutral depending on one's behavior or personality[48].

The values of Cireundeu's local wisdom used as character education include having a sense of social responsibility, actively participating in shared interests, and showing tolerance, independence, and mutual respect. The values of participation and mutual cooperation are the values of local wisdom internalized in character education. As well, the uniqueness of the Indigenous Cireundeu people is seen as having tourism potential for both domestic and foreign tourists. Based on observations, the local wisdom of the Indigenous people there also indirectly shapes creative and innovative character in managing the local environment as a tourist spot. According to Vitasurya, local wisdom was the foundation of sustainable development in rural tourism with community participation and involvement, including developing skills to make home industries to improve the economy of the local community[34]. In the process of realizing character education based on local wisdom, local wisdom makes it possible to continue lifelong character learning in the community, not only to reinforce the economic status of the community based on self-sufficiency but also to strengthen moral values and local culture in the community [49].

\section{The Implementation of Early Age Education Based on Sundanese Local Wisdom in Preparing Global Citizens}

Some research and facts reveal that character education starting from early education can have a positive impact on academic achievement [12] as well as on the development of each individual as a global citizen. Global citizen means tolerance, respect, openness and responsibility for self, others, and the planet. Becoming a global citizen is a complex process in which an individual is influenced by interacting variables such as participation, responsibility, and awareness, as well as most importantly, an individual should have metacognitive capacities that underpin a global mindset [50]. Furthermore, this study found that there are several types of local wisdom in the Indigenous Cireundeu community that can be used as early childhood character education to prepare global citizens. Early childhood education is imperative because this education can develop metacognitive skills, especially on IQ, school readiness, and social and emotional skills [50]. According to Ferdiawan, early childhood education can be a good or bad factor in the quality of one's personality, and a balanced pattern is needed between education, emotions, spirituality, and intellectual personality in improving the quality of children and the need to instill local wisdom values based on education [51]. Based on that description, the influence of Cireundeu's local wisdom on the quality of early character education to prepare global citizens is shown in Table 3. 
Table 3. The Influence of Cireundeu's Local Wisdom on the Quality of Early Age Character Education to Become a Global Citizen

\begin{tabular}{|c|l|l|l|}
\hline No. & Type of Local Sundanese Wisdom & Quality of Early Age Education & Description \\
\hline 1. & $\begin{array}{l}\text { The Principle of Openness } \\
\text { towards Globalisation }\end{array}$ & Intellectual Intelligence & $\begin{array}{l}\text { The Indigenous people of Cireundeu teach critical } \\
\text { thinking to control the effects of globalization }\end{array}$ \\
\hline 2 & Community Service & $\begin{array}{l}\text { The Indigenous community there teaches } \\
\text { collaboration and cooperation in the common } \\
\text { interest with a family spirit }\end{array}$ \\
\hline 3 & $\begin{array}{l}\text { Upholds the History of Ancestral } \\
\text { Struggle }\end{array}$ & The attitude of sympathy and empathy & $\begin{array}{l}\text { The Indigenous people there teach the attitudes that } \\
\text { have human and social values }\end{array}$ \\
\hline 5. & $\begin{array}{l}\text { Local Beliefs } \\
\text { Creativity and Innovation }\end{array}$ & $\begin{array}{l}\text { The Indigenous people there teach the stimulation of } \\
\text { new ideas and independence }\end{array}$ \\
\hline
\end{tabular}

Based on Table 3, the components of early childhood education that aim to develop the personality and character of children in preparing them to become global citizens through the values of Sundanese local wisdom in Cireundeu. Firstly, local wisdom is demonstrated through the principle of the Cireundeu Indigenous people, can develop intellectual intelligence as their early childhood education so that children can have the ability to think critically, rationally, open-mindedness, responsibly and being tolerant to accept differences in Indonesia and the world, in which attitudes and capabilities like this are needed in preparing global citizens. Global competence, stated by Brigham, was defined as having an open mind while actively seeking to understand cultural norms and expectations of others, plus leveraging this gained knowledge to interact, communicate and work effectively outside of one's own environment [52]. Global competence is intelligence intellectuals who meet the components contained such as knowledge, skills, and behavior in the formation of global citizens. Secondly, Cireundeu's next local wisdom, shown by having a mindset of mutual cooperation for the common interest in Cireundeu, collaboration with a spirit of high solidarity, actively participating in activities in Cireundeu and social awareness applied in daily life to interact with the Indigenous community and non-ethnic communities. This local wisdom develops emotional intelligence as early childhood education, in line with the preparation of good global citizens. In accordance to the attitudes of global citizens come from the values of responsibility for global citizenship, serving the community in the sense of prioritizing the common interests of individuals, just as what is stated by the attitudes of global citizens who fulfill the values of the global responsibility civil service, in the sense of prioritizing shared interests over individual interests, and a shared sense of belonging to a universal society across national borders [53].

Thirdly, the skill to communicate the history of the
Indigenous Cireundeu people's ancestors' struggle from generation to generation, to uphold the history of their past struggle along with the sustainability, starting from the history of the Dutch colonial era, at that time, rice was limited, and then the Cireundeu Indigenous people were hit by a drought. It was a concern for the Cireundeuadat holders at the time who demanded that the Cireundeu Indigenous people be free from poverty[54]statesthat during the Dutch colonial era, most rice fields planted suddenly became dry, while the supply of rice from the Dutch government at the time was not enough to meet the needs of the community. It was during these difficult times that the people of the Cireundeu Village began to think hard about overcoming this problem so that their children would not experience the difficulty in accessing food that consisted of their staple foods. Also, the ancestors of the Indigenous people in Cireundeu had predicted that the supply of rice would decrease inversely with an increased demand for rice in the future. Therefore, to anticipate the fact that the next generation would rely on rice as their staple food, the ancestors started not to eat rice and find a suitable substitute for it[54]. Thus, local wisdom upholds the history of the past struggle in Cireundeu as it develops an attitude of sympathy and empathy which global citizens need to have today. A global citizen is a person who thinks globally has a humanitarian and social concern in a global society[55].

Fourthly, the most common and well-known wisdom in Indigenous communities in Cireundeu is to change the staple food from the rice to cassava rice so that every day their staple food is a constellation (cassava rice). In addition, their creativity can be seen in processing food based on cassava plants for their economic resources, so that they indirectly teach the values of independence, creativity, and innovation to their children as early childhood education in preparing creative and innovative global citizens. Saliceti argues that one of the competencies of today's global citizens is to own the quality or ability to 
create [56]. The ability to create new ideas and to have an originality that is to encourage children to have mental global competitiveness .Fifthly, the next local wisdom is the flow of belief in the Cireundeu Indigenous community, namely Sunda Wiwitan, one of the Sundanese streams of belief in West Java, which draws people closer to the universe by teaching values, norms, and morals in Sundanese society. Local wisdom has the potential to grow spiritual intelligence in the formation of character to prepare citizens who have a good and intelligent attitude. As stated by Street, spiritual education helps children develop the skills and attitudes needed to become productive global citizens who respect diverse world views, find peaceful solutions, and show empathy for people from different cultures [11]. Respecting different points of view is very important in creating a type of society where there is an act of mutual respect and openness.

Recently, the importance of education to develop smart global citizens and characters following the national identity cannot be underestimated. As diversity in society is recognized, and local cultural values are included in the dynamics of national and global culture, the intention is to preserve local culture to make each individual adopt a global perspective without ignoring their local or national ethnic identity $[7,15]$. Some local Sundanese wisdom reflects early childhood education as shown in table 3 . The local wisdom principle of the Indigenous Cireundeu people adopts a cosmopolitan way of thinking from an early age by not ignoring the local culture as global citizenship education in their communities. The cosmopolitan approach is global citizenship as the basis of education [14]. Other local wisdom of Cireundeu that has been applied from an early age includes the values and attitudes of global education. The intended global education promotes the values of tolerance and equality, the teaching of the relationship between peace, cultural diversity, human rights and environmental sustainability, along with acceptance and empathy of other cultures [57].

\section{Conclusions}

The dynamics of globalization in the era of the ever-accelerating Industrial Revolution 4.0 make it a necessity for all people in the world to follow its development. The challenge is that some developing countries are not ready to produce citizens with the same competencies as global citizens. In Indonesia, the variety of different ethnicities, cultures, religions, beliefs, languages, and differences in socio-economic backgrounds is an obstacle in preparing global citizens. The implementation of character education based on local wisdom since early childhood in a multicultural country like Indonesia is believed to be a way to increase the competence of its people to become global citizens. This study has brought local Sundanese wisdom to a global level through the implications of early childhood character education implemented sustainably by the Indigenous communities of Cireundeu. In addition, local Sundanese wisdom has an impact on intellectual, emotional, and spiritual intelligence and it can be useful for developing personal skills and abilities. Furthermore, commitment, synergy, and integrity are needed to develop multicultural societies as a means of increasing understanding and harmonization of local and global cultures. Through cross-cultural understanding applied from an early age, each individual is allowed to grow and develop into a global citizen who is intelligent, has character, and could engage in global issues.

\section{Acknowledgments}

We want to thank all colleagues from the Citizenship Education Study Program who assisted the authors in collecting data by reviewing related literature and motivations for the authors. In addition, we would like to thank the Faculty of Teaching and Education at Universitas Muhammadiyah Surakarta for permitting and funding this scientific publication.

\section{REFERENCES}

[1] Sum N, Jessop B. Competitiveness, the Knowledge-Based Economy and Higher Education. 2015;(June).

[2] Ärlemalm-Hagsér E, Davis J. Examining the rhetoric: A comparison of how sustainability and young children's participation and agency are framed in Australian and Swedish early childhood education curricula. Contemp Issues Early Child. 2014;15(3):231-44.

[3] Ellis M. The Critical Global Educator: Global Citizenship Education as Sustainable Development. 2015; Available from:

https://books.google.com.br/books?hl=pt-BR\&lr=\&id=vzq DCgAAQBAJ\&oi=fnd\&pg=PP1\&dq=\%22affective+comp uting\%22+"affective+OR+state",+OR+"affective+OR+asp ect",+OR+"modelo+OR+afetivo",+OR+"affective $+\mathrm{OR}+\mathrm{mo}$ de

[4] Lilley K, Barker M, Harris N. The Global Citizen Conceptualized: Accommodating Ambiguity. J Stud Int Educ. 2017;21(1):6-21.

[5] Lilley K, Barker M, Harris N. Exploring the Process of Global Citizen Learning and the Student Mind-Set. J Stud Int Educ. 2015;19(3):225-45.

[6] Jati WR. Bonus Demografi Sebagai Mesin Pertumbuhan Ekonomi: Jendela Peluangatau Jendela Bencana di Indonesia. Populasi. 2015;

[7] Malihah E. An ideal Indonesian in an increasingly competitive world: Personal character and values required to realise a projected 2045 'Golden Indonesia.' Citizenship, Soc Econ Educ. 2015;14(2):148-56. 
[8] Flower G. Editorial insights. Screen Print. 2011;101(5):48.

[9] Karakatsani D, Zorbas V. Identity in Times of Crisis , Globalization and Diversity: Practice and Research Trends. 2018. $1-589$ p.

[10] Sulisworo D. The Contribution of the Education System Quality to Improve the Nation's Competitiveness of Indonesia DwiSulisworo (2016). The Contribution of the Education System Quality to The Contribution of the Education System Quality to Improve the Nation' $\mathrm{s}$. 2016;(October).

[11] Street M, Helterbran VR, Strahler BR. Children as Global Citizens. 2013;(October 2014):37-41.

[12] A. Kamaruddin S. Character Education and Students Social Behavior. J Educ Learn. 2012;6(4):223.

[13] Broom C. Empowering students: Pedagogy that benefits educators and learners. Citizenship, Soc Econ Educ. 2015;14(2):79-86.

[14] Enslin P. Education for Global Citizenship: The Cosmopolitan and the Patriotic. Citizenship, Soc Econ Educ. 2012;10(2-3):91-100.

[15] Watson S. An exploration into the teaching of cosmopolitan ideals: The case of "global citizenship." Citizenship, Soc Econ Educ. 2013;12(2):110-7.

[16] Lilley K, Barker M, Harris N. Exploring the Process of Global Citizen Learning and the Student Mind-Set. J Stud Int Educ. 2015;19(3):225-45.

[17] Soland J, Hamilton LS, Stecher BM. Measuring 21st century competencies: Guidance for educators. Asia Soc Glob Cities EducNetw Rep [Internet]. 2013;(November):68. Available from:

http://asiasociety.org/files/gcen-measuring21 cskills.pdf

[18] Yanzi H, Hidayat OT, Mentari A, Budimansyah D. Global Citizens Awareness through Digital Literacy in the Fourth Industrial Revolution: A Review of the Literature. 2019;317(IConProCS):65-9.

[19] Wagiran. Pengembangan karakter berbasis kearifanlokal. J Pendidik Karakter. 2012;II(3):329-39.

[20] C. A. 2007.. N. U. http://cuip. uchicago. edu/ cac. pubs. ht. Cunningham, Character Education in Public Schools: The Quest for a Suitable Ontology. National Louis University, 2007.

[21] Thirachai C, Sunthorapot D. Development and validity testing of belief measurement model in Buddhism for junior high school students at Chiang Rai Buddhist Scripture School: An application for Multitrait-Multimethod analysis. Educ Res Rev. 2016;11(18):1731-40.

[22] Betawi A. Calling for character education: promoting moral integrity in early childhood education in Jordan. Early Child Dev Care [Internet]. 2020;190(5):738-49. Available from: https://doi.org/10.1080/03004430.2018.1489383

[23] Acat MB. Okulların Karakter Eğitimi Yetkinliği Ölçeği (OKEYÖ). Değerler Eğitimi Derg. 2011;9(21):7-27.

[24] Lee A. Implementing character education program through music and integrated activities in early childhood settings in Taiwan. Int J Music Educ. 2016;34(3):340-51.
[25] Bates A. Character education and the "priority of recognition.' Cambridge J Educ [Internet]. 2019;49(6):695-710. Available from:https://doi.org/10.108 0/0305764X.2019.1590529

[26] Priest C. Incorporating character education into the early childhood degree program: The need, and one department's response. J Early Child Teach Educ. 2007;28(2):153-61.

[27] Sanderse W. The meaning of role modelling in moral and character education. J Moral Educ. 2013;42(1):28-42.

[28] Turan F, Ulutas I. Using storybooks as a character education tools. J EducPract. 2016;7(15):169-76.

[29] Jean Piaget, The Moral Judgment of The Child. New York: The Free Press, 1965

[30] Lee GL. Re-emphasizing Character Education in Early Childhood Programs: Korean Children's Experiences. Child Educ. 2013;89(5):315-22.

[31] Shubert J, Wray-Lake L, Syvertsen AK, Metzger A. The role of family civic context in character development across childhood and adolescence. Appl Dev Sci [Internet]. 2019;0(0):1-16. Available from: https://doi.org/10.1080/10 888691.2019 .1683452

[32] Hidayat OT, Budimansyah D. Civic Culture Paradigms Brin Hidayat, O. T., \& Budimansyah, D. (2018). Civic Culture Paradigms - Bringing Sundanese Local Wisdom to Modern Society.

https://doi.org/10.5220/0007113412101217ging Sundanese Local Wisdom to Modern Society. In ScitePress; 2018.

[33] Ramadhan IR, Djono D, Suryani N. Local Wisdom of Kasepuhan Ciptagelar: The Development of Social Solidarity in The Era of Globalization. Int J Multicult Multireligious Underst. 2018;5(3):35.

[34] Vitasurya VR. Local Wisdom for Sustainable Development of Rural Tourism, Case on Kalibiru and Lopati Village, Province of Daerah Istimewa Yogyakarta. Procedia SocBehavSci [Internet]. 2016;216(October 2015):97-108. Available from: http://linkinghub.elsevier.com/retrieve/pii/ S1877042815061947

[35] Gardner-McTaggart A. International elite, or global citizens? Equity, distinction and power: the International Baccalaureate and the rise of the South. Glob Soc Educ. 2016;14(1):1-29.

[36] Engle PL, Black MM, Behrman JR, Mello MC De. Child development in developing countries 3 : Strategies to avoid the loss of ... Lancet. 2007;369:229-42.

[37] Mcgranahan C. (folk, the people) and. 2018;

[38] Hidayat OT, Lokal NK, Cireundeu A, Penguat U, Kewarganegaraan B. Obby Taufik Hidayat, 2017 NILAI-NILAI KEARIFAN LOKAL ADAT CIREUNDEU UNTUK PENGUAT BUDAYA KEWARGANEGARAAN MASYARAKAT Universitas Pendidikan Indonesia repository.upi.edu | perpustakaan.upi.edu. :1-11.

[39] Etikan I, Musa SA, Alkassim RS. Comparison of Convenience Sampling and Purposive Sampling Comparison of Convenience Sampling and Purposive Sampling. Am J TheorAppl Stat. 2016;5(January 2016):1-5.

[40] Ospina SM, Esteve M, Lee S. Assessing Qualitative Studies 
in Public Administration Research. Public Adm Rev. 2018;78(4):593-605.

[41] Belotto MJ. Data analysis methods for qualitative research: Managing the challenges of coding, interrater reliability, and thematic analysis. Qual Rep. 2018;23(11):2622-33.

[42] [42] Baltacı A. Nitel Veri Analizinde Miles-Huberman Modeli. Ahi Evran Üniversitesi Sos Bilim Enstitüsü Derg[Internet]. 2017;3(1):1-15. Available from:http://dergi park.gov.tr/download/article-file/318527

[43] Potrafke N. The evidence on globalisation. World Econ. 2015;38(3):509-52.

[44] Cheng YC. Fostering local knowledge and human development in globalization of education. Int J EducManag [Internet]. 2004; 18(1):7-24. Available from: http://search.ebscohost.com/login.aspx?direct=true $\& \mathrm{db}=$ eue $\& A N=56508380 \&$ site $=$ ehost-live $\% 5$ Cnhttp://www.emerald insight.com/doi/pdfplus/10.1108/09513540410512109

[45] Nurhayanto P, Wildan D. Transformasi Nilai-Nilai Kearifan Lokal Masyarakat Adat Cireundeu. Sosietas. 2016;6(1).

[46] Siddiqa A, Hussain T, Qasim M, Javed MI. The Impact of Globalization on Unemployment and Economic Growth: Pane $1 \mathrm{Da}$ ta Analysis for Developing Countries. Bull Bus Econ [Internet]. 2018; 7(3):122-31. Available from: http://rfh.org.pk/jur/wp-content/uploads/2018/12/BBE-73-1 22-131.pdf

[47] Dev K. Globalization, Teacher Education and ICT (Information and Communication Technology). 2017; 2(4):393-5.

[48] Murray E, ... MB-TJ of C, 2019 undefined. Leading With and for Character: The Implications of Character Education Practices for Military Leadership. JcliScholasticahqCom [Internet]. 2017; Available from: http s://jcli.scholasticahq.com/article/7520.pdf

[49] Ratana-Ubol A, Henschke JA. Cultural Learning Processes through Local Wisdom: A Case Study on Adult and Lifelong Learning in Thailand. Int $\mathrm{J}$ Adult VocatEduc Technol. 2015;6(2):41-60.

[50] Jooste N, Heleta S. Global Citizenship Versus Globally Competent Graduates. J Stud Int Educ. 2016;21(1):39-51.

[51] Ferdiawan E, Putra WE. Esq Education for Children Character Building based on Phylosophy of Javaness in Indonesia. Procedia - SocBehav Sci. 2014;106:1096-102.

[52] Brigham M, Ph D. Creating a Global Citizen and Assessing Outcomes. 2011;1(1).

[53] Woosnam KM, Strzelecka M, Nisbett GS, Keith SJ. Examining millennials' global citizenship attitudes and behavioral intentions to engage in environmental volunteering. Sustain. 2019;11(8):13-6.

[54] Sumiati E, Hufad E. Study of Indigenous Peoples Empowerment Model in Cireundeu Village. 2016;73-6.

[55] Cameron JD. Communicating Cosmopolitanism and Motivating Global Citizenship. Polit Stud. 2018; 66(3):718-34.

[56] Saliceti F. Educate for Creativity: New Educational Strategies. Procedia - SocBehavSci [Internet]. 2015; 197(February):1174-8. Available from: http://dx.doi.org/10 $.1016 /$ j.sbspro.2015.07.374

[57] Horsley M, Newell S, Stubbs B. The Prior Knowledge of Global Education of Pre-Service Teacher Education Students. Citizenship, Soc Econ Educ. 2010;6(3):137-55. 